\title{
COMMUNITY INVOLVEMENT
}

A contribution from the Nursing Section of the Department of Health

\section{OPSOMMING}

Die verpleegkundige het nog altyd 'n groot rol gespeel om die gemeenskap te stimuleer tot deelname in gesondheidsaktiwiteite. Haar werk as verpleegkundige bring mee dat sy in aanraking kom met al die verskillende sosio-ekonomiese groepe in privaathuise, fabrieke, hospitale, klinieke en mobiele eenhede.

Sy funksioneer in verskillende afdelings van verpleging as lid van 'n multi-dissiplinêre span. Sy ken die gemeenskap waarin sy werk en kan dus optree as motiveerder.

In Psigiatriese dienste is reeds verskeie "Vriende-groepe" gevorm byvoorbeeld "Vriende van Umgeni" wat omsien na die Psigo-sosiale behoeftes van die pasiënte. Hierdie ondersteuning van vriende en naasbestaandes is nodig om die pasiënt behulpsaam te wees met heraanpassing in die samelewing.

Ouers van kinders met genetiese afwykings het 'n behoefte om groepe te stig byvoorbeeld “Down's Sindroom-groep" en sodoende mekaar te ondersteun. Die groepe het noue kontak met die mediese span en word op hoogte gehou met die wyse van hantering van hul kinders.

Gemeenskapsbetrokkenheid is geen nuwe begrip in die Suid-Afrikaanse gemeenskap nie, soos spreek uit die inhoud van die artikel.

\section{INTRODUCTION}

COMMUNITY involvement is the main theme of $C_{\text {Health Year. Governments have a responsibility for }}$ the health of their people, and in this country under the present 3-tier system of government, the responsibility for the rendering of health services is divided between central, provincial and local government. However, under our democratic system, all people have the right to, and it is indeed their duty, to participate individually 
and collectively in the planning and implementation of services to meet their health needs. Ultimately, through involvement of individuals, families and communities, greater self-reliance is achieved leading to greater responsibility being assumed by people for their own health.

With regard to health manpower many nations in Africa and also other countries in the world are a long way from achieving the target set by the W.H.O. namely that of providing one doctor for every 10000 of the population. In many countries there are also not enough other trained health professionals.

In Southern Africa we are more fortunate since there are large numbers of well-trained nurses available. During 1978 there were 51120 nurses on the registers and rolls of the South African Nursing Council. Despite this, we are forced to rely increasingly on the self-help potential of the community.

What do we mean by the concept "community". It is one of the most ambiguous terms in sociology. Most books refer to it as a grouping of people organized around residential units or households and based on daily patterns of interaction. "A community may be six houses together in the middle acres of farmland, or millions of people squeezed together in a metropolis. It can be a town of 2000 or a small neighbourhood within a large city"'. $(3,564)$

Certain common elements characterise all these groups. They are based on the residential unit and are organized around patterns and activities that occur on a very regular or daily basis: shopping, schools, work, church, local government, and some forms of recreation.

After such a comprehensive definition, it is clear that a community can be outlined on a geographical basis or on the basis of community interests and patterns of living.

To involve means "to envelop within the folds of some condition or circumstance." (Oxford Dictionary)

\section{THE ROLE OF THE COMMUNITY HEALTH NURSE IN COMMUNITY INVOLVEMENT}

The community health nurse works in a defined setting and she must know the community with which she works. She must know its traditions and structure; its customs and practices. As a key-figure in the community, with the ideal of bringing about lasting results with regard to good health practices, it is essential that she understands and respects the values and practices of the people with whom she works. New ideas or actions should be moulded into the existing cultural framework. She must manipulate the community in such a way that a sudden spark of insight that could lead to action in a desirable way, must originate from the community itself.

Community involvement is not a separate scientific discipline. It does, however, have a few operational techniques which must be mastered. The essence of these techniques is successful person-to-person communication between the community health nurse and the community she serves.

The knowledge that is applied in community development is the specific expertise of the nurse, the doctor, the social worker, the occupational therapist, dietician, etcetera - depending on whose expert knowledge is needed in any particular situation. That is why community involvement demands an interdisciplinary approach. The community health nurse cannot work in isolation. She is part of a team and must make sure that she understands her role in the team.

\section{COMMUNITY INVOLVEMENT: GENETIC SERVICES}

The Genetic Service of the Department of Health has recognised the importance of community involvement in the support and care needed by parents who have had a child affected by a genetic disorder. Parents react differently to the birth of such a child. All parents go through stages of mourning. Some react by overprotection, others by rejection.

An empathetic understanding will facilitate the effective management of problems encountered by parents with an affected child.

The child should be investigated by a medical team and assistance given to the mother so that she can feed and care for her child and obtain the satisfaction of response on the part of the child.

To achieve adjustment the parents need help not only of an empathetic counseller, but also of those who are in the same position as themselves.

\section{DOWN'S PARENT GROUPS}

The Down's parent groups were initiated to provide support and practical help in caring for their children. The groups meet informally at regular intervals. These groups may be initiated by the Genetic Sister or other health professionals but are organised and administered by the community.

The Down's parent groups arrange for specialists in the field to attend their meetings for lectures, discussions and guidelines concerning the care and management of their child.

In this group situation where there are others who have the same problems, the parents gain support and encouragement from people with first hand experience. They are afforded the opportunity to share experiences, discuss problems and learn from the way in which other people are coping. The mother should be trained to play an active role in the treatment, education and care of her affected child.

"There is no reason why any person - teacher, nurse, therapist or parent with insight into the needs and problems involved and with access to available resources - should not organize parent groups." (J. Opt'Hof: Down's Syndrome, Genetic Services, Department of Health, p.23).

Although the Down's parent group has been mentioned here it must be realised that there are many fellowship groups in existence e.g. Haemophilic Foundation, Cystic Fibrosis Foundation, parents and friends.

The principle of community involvement in providing for the psychosocial needs of its members, plays an important role in the concept of comprehensive health care. 


\section{COMMUNITY INVOLVEMENT IN A FAMILY PLANNING PROGRAMME}

Four sources of family planning care can be identified:

* the public sector: central, provincial and local government family planning services

* the private sector: private doctors, nurses, pharmacists, and organizations who provide service on a commercial basis

* the informal sector consisting of self-care, care from family, neighbours, friends, and volunteers

* voluntary organizations

\section{The Public Sector}

Several factors limit the effectiveness of public family planning services in reaching the desired end-result. One is the cost of such services. Another is the rising expectations of the population regarding the extension of family plarıning services, particularly if there is inadequate co-operation on the part of the community. Hence the necessity to involve other sources of family planning care, namely the informal sector and voluntary organisations. Although grossly neglected, it has been proven that the public sector is able to obtain community involvement where family planning officials have accepted this as a key result area. Community involvement is not considered to be the prerogative of voluntary organisations. There is a vast amount of self-care and initiative present in every community, and official workers should do everything to exploit it, and cease activities which suppress it.

\section{Informal Section and the Official Family Planning Worker}

A vital concept is voluntary workers unattached to any particular organization in the supplementary services of the family planning programme. Volunteers can be involved by family planning officials as family planning counsellors, or as family health educators to inform people in understandable terms about planning a family, about health risks in pregnancy and how to cope with specific contraceptive problems. Family planning or contraceptive information is not to be regarded as a field over which there is professional monopoly, but as common knowledge which must be widely shared in the community. Official family planning workers must, however, adapt to the use of volunteers and stop using only qualified personnel. The approach of the officials in their relationship with volunteers must be one of partnership and not of competition or conflict. Community involvement must be accepted for what it is; an essential ingredient to reach the desired end-result.

Another important concept is community development. Here communities are assisted by officials to organise themselves and to operate on a mutual aid basis. The possibilities are endless. Consider for example the community wishing to establish their own crèche or mother and child health services and family planning projects. Under the indirect guidance of family planning officials the community itself enlists the assistance of volunteers in the community who could possibly contribute in establishing such ventures e.g. artisans, teachers, nurses, mothers taking turns at keeping services going. Again official involvement must be minimal. This contrasts with the present system of providing an official service with no active involvement whatsoever on the part of the community.

A last example of community involvement by officials is the scheme of encouraging employers to assist in meeting the family planning needs of their employees. This project has proved the potentiating effect of volunteers in the attainment of the goals of the family planning programme.

\section{Voluntary Organizations}

Regarding the use of voluntary organizations, many problems would disappear if the organizations are seen to be competent, efficient, energetic and informed about the needs of their community and that they are working in harmony with public services, particularly if they are financed from public funds. Perhaps the greatest need is for voluntary organizations to take a good hard look at their activities and their achievements, and then to take whatever drastic and courageous action is necessary for an honest answer. For their survival too, it is necessary to attain greater community involvement and to adjust their activities to the real needs of the community.

Volunteers will be attracted if the organization is seen to be prepared to act on new ideas, to accept modern methods of work and willing to give newcomers a chance. To achieve success in community involvement it is better to have many people making small contributions, rather than a few spending all their time and effort.

The involvement of the informal and voluntary sectors in an official programme represents the greatest single advance which officials can make in the achievement of the end-result of a family planning programme, namely improvement of the socio-economic and health status of families.

\section{COMMUNITY INVOLVEMENT IN A PSYCHIATRIC PROGRAMME}

In the community there are numerous facilities promoting mental health but there is still a need for community involvement to support the mentally disturbed and retarded.

The modern concept of therapy involves treatment of the patient in the community instead of a hospital. A large number of clinics, ranging from psychiatric hospitals to the mental health societies, function in furtherance of this aim. The clinics are distributed throughout the country to bring the service as close to the patient as possible.

If the admission of the patient to a psychiatric hospital is inevitable, he is hospitalized for a short period only.

The sympathetic attitude and support of the community is of great importance when the patient is discharged. At this stage the parents, friends and relatives will have to integrate the patient into family life. The family is informed about the patient's condition and they are prepared for his return home. The cooperation of the patient's employer and colleagues is 
essential for his resocialization and recovery.

In many instances patients are "adopted" by friends and even strangers who are willing to care for them after discharge. The personal interest and loving care give these patients a sense of belonging. At several psychiatric hospitals "Friends of" organizations are established which consist of friends and relatives of patients as well as members of the community, for example "Friends of Umgeni," "Friends of Fort Napier".

Members of these organizations act as voluntary workers in the hospitals. Their services are invaluable because they assist in the stimulation of the patients, resocialization, encouraging interaction and teaching social, and interpersonal skills. They assist the patient when performing simple tasks like using the telephone or taking the bus.

Some of the women or church organizations "adopt" a certain ward in a psychiatric hospital. Once a month they have a tea party in the ward. By involving the community during the period of hospitalization, the patient gradually adapts to life in the community.

Patients are allowed to attend church gatherings in the community and after the service they join in having tea with the other members of the congregation.

In many psychiatric hospitals members of the community are members of the sport club of the hospital.

The strongly-felt need for community involvement led to the establishment of mental health societies. By means of mental health education these societies provide a preventative service.

Curative services are provided at different clinics for patients for consultation with the psychiatrist, the psychiatric nurse and the social worker.
Hostels, protective workshops as well as day care centres are also provided for mentally handicapped persons. Most of these institutions are financed by donations from the community, for example the Pumla and Pumelela Day Care Centres for black mentally retarded children.

Hence, there are strong indications that members of the community should be sensitive to the needs of their fellow men. Without the help and the involvement of the community it will not be possible to fulfill the concept of "a healthy mind in a healthy body."

\section{CONCLUSION}

It is quite obvious from the discussion that community involvement is not really a new concept. In South Africa we have many examples of community involvement especially in our smaller communities.

It is the responsibility of the community health nurse to promote community involvement. Because of her relationship with the public at all levels of community life, whether through schools, prisons, private homes, institutions, clinics and factories. She is in an ideal position to do so. A tremendous challenge - is she prepared to meet it?

BIBLIOGRAPHY

1. Botha, H. P. Dr.: Self-Help (a lecture given by Dr. Botha)

2. Opt'Hof, J. Dr. Down's Syndrome, Genetic Services, Department of Health

3. Popenoe, D.: Sociology. (Practice, Inc-New Jersey)

4. Roux, J. P. Dr.: The Pracical Importance of Community Development (Notes from the Committee on C.D.) 